\title{
ANTIOXIDANTS, SUCROSE AND AGAR IN THE IN VITRO MULTIPLICATION OF Eremanthus incanus
}

\author{
Natane Amaral Miranda ${ }^{1 *}$, Miranda Titon² ${ }^{2}$ Israel Marinho Pereira², José Sebastião Cunha Fernandes ${ }^{3}$, Marcone \\ Moreira Santos ${ }^{1}$, Rafaela Naiara de Oliveira ${ }^{4}$
${ }^{1 *}$ Federal University of Viçosa, Graduate Program in Forest Science, Viçosa, Minas Gerais, Brazil - nataneamaral@gmail.com*; marconemoreirasantos@hotmail.com
${ }^{2}$ Federal University of Vales of Jequitinhonha and Mucuri, Department of Forestry, Diamantina, Minas Gerais, Brazil - mirandatiton@gmail.com; imarinhopereira@gmail.com
${ }^{3}$ Federal University of Vales of Jequitinhonha and Mucuri, Department de Agronomia, Diamantina, Minas Gerais, Brazil - jscf1912@gmail.com \\ ${ }^{4}$ Forestry, Corinto, Minas Gerais, Brazil - rafaelan.oliveira@ hotmail.com
}

Received for publication: 22/03/2017- Accepted for publication: 20/03/2018

\begin{abstract}
The objective of this study was to evaluate the in vitro multiplication of Eremanthus incanus axillary buds in the presence of PVP additives and activated charcoal under the interaction of different sucrose and agar concentrations. Explants containing axillary buds were inoculated in MS culture medium to evaluate the effect of $0.8 \mathrm{~g} \mathrm{~L}^{-1}$ of PVP and 1.0, 2.0 and $4.0 \mathrm{~g} \mathrm{~L}^{-1}$ of activated charcoal. The results of the addition of $0,15,30$, and $60 \mathrm{~g} \mathrm{~L}^{-1}$ of sucrose combined with concentrations of 6 and $10 \mathrm{~g} \mathrm{~L}^{-1}$ of agar in MS medium were also evaluated. The number and quality of emitted shoots were evaluated after 30 and 60 days. The addition of PVP to the culture medium was more efficient than the use of activated charcoal in the multiplication of the species. The presence of sucrose is indispensable for developing the shoots well, and the use of a lower concentration of agar favors the development of quality shoots. The best results for shoot multiplication were obtained using 30 $\mathrm{g} \mathrm{L}^{-1}$ sucrose and $6 \mathrm{~g} \mathrm{~L}^{-1}$ agar. PVP, activated charcoal, agar and sucrose are important components in the culture medium and alter the in vitro multiplication of Eremanthus incanus.

Keywords: Tissue culture, micropropagation, culture medium.
\end{abstract}

\section{Resumo}

Antioxidantes, sacarose e ágar na multiplicação in vitro de Eremanthus incanus. O objetivo deste estudo foi avaliar a multiplicação in vitro de gemas axilares de Eremanthus incanus na presença dos aditivos polivinilpirrolidona - PVP e carvão ativado, e a interação de diferentes concentrações de sacarose e ágar. Os explantes que continham gemas axilares foram inoculados em meio de cultura MS para avaliar o efeito de $0,8 \mathrm{~g} \mathrm{~L}^{-1}$ de PVP e 1,0, 2,0 e 4,0 $\mathrm{g} \mathrm{L}^{-1}$ de carvão ativado. Avaliou-se também o resultado da adição de $0,15,30$ e $60 \mathrm{~g} \mathrm{~L}^{-1}$ de sacarose, combinado com concentrações de 6 e $10 \mathrm{~g} \mathrm{~L}^{-1}$ de ágar em meio MS. Após 30 e 60 dias, foram avaliados o número e a qualidade das brotações emitidas. A adição de PVP ao meio de cultura foi mais eficiente que o uso de carvão ativado na multiplicação da espécie. A presença de sacarose é indispensável para o bom desenvolvimento das brotações, assim como o uso de menor concentração de ágar favorece o desenvolvimento de brotos de qualidade. Os melhores resultados para a multiplicação das gemas foram obtidos utilizando $30 \mathrm{~g} \mathrm{~L}^{-1}$ de sacarose e $6 \mathrm{~g} \mathrm{~L}^{-1}$ de ágar. PVP, carvão ativado, ágar e sacarose são componentes importantes no meio de cultura e alteram a multiplicação in vitro de Eremanthus incanus.

Palavras-chave: Cultura de tecidos, micropropagação, meio de cultura.

\section{INTRODUCTION}

Eremanthus incanus (Less.) Less is a forest species popularly known as Candeia and has great importance for Brazilian biodiversity, from which high-value products used by the cosmetic and pharmaceutical industries such as essential oil and $\alpha$-bisabolol are extracted, and they are also widely used as fence posts for presenting highdurability wood (SCOLFORO et al., 2012).

As this species has a great economic, ecological and social value (SCOLFORO et al., 2012), it is important to have greater attention and research performed regarding its propagation, aiming at improving multiplication techniques for possible applications in homogeneous plantations, recovery of degraded areas, genetic improvement and conservation of germplasm.

FLORESTA, Curitiba, PR, v. 48, n. 3, p. 311-320, jul/set. 2018.

Miranda. N. A. et.al.

ISSN eletrônico 1982-4688

DOI: $10.5380 /$ rf.v48 i3.51365 
The maximization of genetic gains by selection occurs in species where commercial plantings are carried out via vegetative propagation, since in addition to exploring all genetic variance, the improved unit for commercial recommendation is composed of a single clone. For this reason, vegetative propagation techniques are the basis of clonal forestry, currently representing one of the main processes of seedling production (XAVIER $e t$ al., 2013). Clonal propagation represents an alternative in situations in which the species presents limitations in its sexual propagation, and it has been widely used for forest species as it allows the multiplication of selected genotypes, conservation of germplasm and studies in general.

Plant micropropagation is certainly among the main available techniques for producing vegetative propagating material. Among its advantages we can point out rapid production of propagation materials which are free of diseases and pests, and with high genetic quality in reduced time and space. As a consequence, it is possible to produce large quantities of uniform plants under controlled conditions, without the influence of climatic variations (ROCHA, 2009).

Studies focused on the cloning of native Brazilian forest species are still scarce. Currently applications of micropropagation of native species are mainly destined to: genotypes considered to be difficult to multiply by traditional propagation methods (PINHAL et al., 2011); those which produce secondary metabolites of pharmacological interest (SOUZA et al., 2011); to the in vitro germplasm conservation of endangered species (CAMPOS et al., 2013); and to the development of molecular biology techniques.

Although studies on the micropropagation of native forest species are still limited, we must consider the importance of these studies which can significantly contribute to the commercial production of high-interest species, enabling their rapid multiplication on a large scale and in a short period of time.

Therefore, the objective of this study was to evaluate the influence of antioxidants, sucrose and agar on the in vitro multiplication of Eremanthus incanus axillary buds. The evaluated hypotheses were that the use of higher concentrations of antioxidants provides greater production of vigorous shoots and there is an interaction between the sucrose and agar concentrations with the increase in Eremanthus incanus shoot multiplication.

\section{MATERIAL AND METHODS}

\section{Plant material and growing conditions}

The experiments were conducted at the Forest Improvement Laboratory of the Forest Engineering Department of the Federal University of Vale of Jequitinhonha and Mucuri (UFVJM), in the municipality of Diamantina, state of Minas Gerais, Brazil, between October 2013 and December 2014. The botanical material of the species composes the databank of the Jeanine Felfili Dendrologic Herbarium, whose collection is registered as HDJF - 3988.

In vitro germinated plants free of contamination were used as donor sources for the explants, which consisted of nodal segments of approximately $2 \mathrm{~cm}$, containing two axillary buds. All experiments used MS culture medium for germination (MURASHIGE; SKOOG, 1962) supplemented with $100 \mathrm{mg} \mathrm{L}^{-1}$ of mioInositol and $\mathrm{pH}$ adjusted to $5.8 \pm 0.02$ prior to the inclusion of MERCK® agar. The medium was autoclaved for 15 minutes at $121^{\circ} \mathrm{C}$ and $1 \mathrm{~atm}$ pressure, and then cooled before plant material inoculation. After inoculation, the experiments were conducted in a culture room at a temperature of $25 \pm 2{ }^{\circ} \mathrm{C}$, photoperiod of 16 hours and light intensity of $40 \mu \mathrm{mol} \mathrm{m} \mathrm{m}^{-2}$.

\section{Experiment 1 - Polyvinylpyrrolidone (PVP) and activated charcoal}

The explants were taken from plants of the sixth subculture, kept in multiplication medium containing $1.0 \mathrm{mg} \mathrm{L} \mathrm{L}^{-1}$ of benzylaminopurine (BAP) and $0.5 \mathrm{mg} \mathrm{L}^{-1}$ of naphthalene acetic acid (NAA). One explant was inoculated per test tube $(25 \times 150 \mathrm{~mm})$ containing $10 \mathrm{~mL}$ of culture medium supplemented with $30 \mathrm{~g} \mathrm{~L}^{-1}$ of sucrose, $1.0 \mathrm{mg} \mathrm{L}^{-1} \mathrm{BAP}, 0.5 \mathrm{mg} \mathrm{L}^{-1} \mathrm{NAA}$, and $6.0 \mathrm{~g} \mathrm{~L}^{-1}$ of agar. Different concentrations of antioxidants were added to this medium: $0.8 \mathrm{~g} \mathrm{~L}^{-1}$ PVP (PVP 0.8) and 1.0; 2.0 and $4.0 \mathrm{~g} \mathrm{~L}^{-1}$ of activated charcoal (AC1, AC2, and AC4, respectively).

The experiment was installed in a completely randomized design (CRD) with four treatments, four replicates, and plots composed of six tubes with one explant each. This experiment consisted of two subsequent cultures (subcultures 1 and 2) with intervals of 30 days, with the previously described procedures being repeated in each of them.

\section{Experiment 2 - Sucrose and agar concentrations}

Explants were individually inoculated into test tubes containing $10 \mathrm{~mL}$ of culture medium, supplemented with $0.8 \mathrm{~g} \mathrm{~L}^{-1}$ PVP, $1.0 \mathrm{mg} \mathrm{L}^{-1}$ BAP and $0.5 \mathrm{mg} \mathrm{L}^{-1}$ NAA. Different combinations of sucrose $(0 ; 15 ; 30 \mathrm{and} 60 \mathrm{~g}$ $\left.\mathrm{L}^{-1}\right)$ and agar $\left(6\right.$ and $\left.10 \mathrm{~g} \mathrm{~L}^{-1}\right)$ were tested.

The eight treatments (four concentrations of sucrose and two concentrations of agar) were arranged in a $4 \times 2$ factorial scheme and installed in a CRD with four replicates and plots composed of five tubes with one 
explant each. This experiment consisted of the initial culture and a subsequent culture (subculture 1) at intervals of 30 days, with the previously described procedures being repeated in each of them.

\section{Evaluation and statistical analysis of data}

All experiments were evaluated at the end of each cultivation considering: the visual aspect (vigor) of the shoot, classified on a scale from 0 to 3 (in which: 0 - oxidized, 1 - low, 2 - medium and 3 - high); the percentage of tubes with presence of leaf chlorosis; the number of leaves; the longest leaf length; and the number of emitted shoots. For the evaluations, only the tubes containing live plants were considered in each replicate for calculation of the means, except for the vigor variable.

Data were submitted to analysis of variance, mean tests and regression analysis using the R software version 3.0.1 (R CORE TEAM, 2013), as well as the ExpDes.pt (FERREIRA et al., 2013) and Stats packages (R CORE TEAM, 2013).

\section{RESULTS}

\section{Experiment 1 - PVP and activated charcoal}

A significant effect of the use of PVP and activated charcoal was observed for the characteristics: vigor (Figure 1), chlorosis and number of leaves in subculture 1, and for the characteristics vigor and number of shoots in subculture 2 (Table 1).

Table 1. Results of the analysis of variance for the characteristics of vigor, chlorosis, leaf number (LN), length of the longest leaf (LL), and number of shoots (NS) in subcultures 1 and 2 for E. incanus, in response to the use of PVP and activated charcoal.

Tabela 1. Resultado da análise de variância para as características vigor, percentual de clorose, número de folhas (LN), comprimento da maior folha (LL) e número de brotações (NS) nos subcultivos 1 e 2 para E. incanus, em resposta ao uso de PVP e carvão ativado.

\begin{tabular}{cccccc}
\hline & \multicolumn{5}{c}{ Subculture 1 } \\
\cline { 2 - 6 } & Vigor & Chlorosis & LN & LL & NS \\
\hline Treatment $(P)$ & $0.0012^{* *}$ & $0.0158^{*}$ & $0.0016^{* *}$ & $0.0576^{\mathrm{ns}}$ & $0.0574^{\mathrm{ns}}$ \\
$\mathrm{CV}(\%)$ & 28.53 & 38.46 & 13.73 & 26.04 & 28.43 \\
\hline & Vigor & Chlorosis & LN & LL & NS \\
\cline { 2 - 6 } & $0.0009^{* * *}$ & $0.9562^{\mathrm{ns}}$ & $0.0799^{\text {ns }}$ & $0.1971^{\mathrm{ns}}$ & $0.0069^{* *}$ \\
\hline Treatment $(P)$ & 39.82 & 53.35 & 43.97 & 36.44 & 13.36 \\
CV $(\%)$ & & & Subculture 2 & \\
\end{tabular}

CV: Coefficient of Variation; $P$ : threshold probabilities in ANOVA with four treatments. *: $\mathrm{P}<0.05 ; * *: \mathrm{P}<0.01 ; * * *: \mathrm{P}<0.001 ;$ ns: $\mathrm{P}>0.05$.

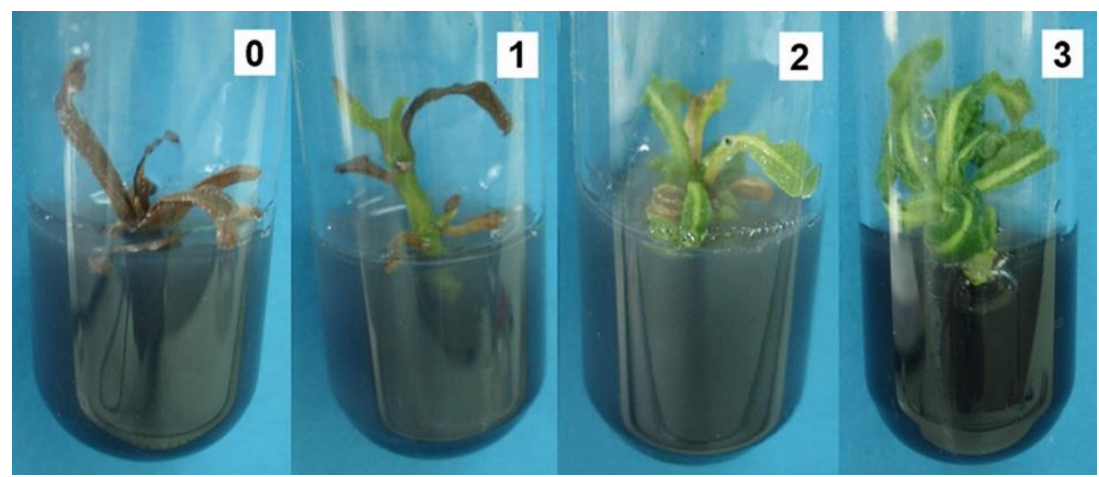

Figure 1. Classification of the vigor nodal segments of Eremanthus incanus depending of the treatments. 0) oxidized, 1) low, 2) medium and 3) high.

Figura 1. Classificação do vigor de explantes de Eremanthus incanus em função dos tratamentos. 0) oxidado, 1) baixo, 2) médio e 3) alto. 
A lower vigor was observed with the use of $1.0 \mathrm{~g} \mathrm{~L}^{-1}$ of activated charcoal for subculture 1 , and of 1.0 and $2.0 \mathrm{~g} \mathrm{~L}^{-1}$ of activated charcoal for the second subculture. Higher rates of leaf chlorosis were obtained using $1.0 \mathrm{~g} \mathrm{~L}^{-1}$ of charcoal in subculture 1; however, this was the one that presented the highest number of leaves. In relation to the number of shoots in subculture 2, the addition of 1.0 and $2.0 \mathrm{~g} \mathrm{~L}^{-1}$ of charcoal resulted in lower values when compared to the use of PVP at $0.8 \mathrm{~g} \mathrm{~L}^{-1}$ (Table 2).

The addition of $0.8 \mathrm{~g} \mathrm{~L}^{-1}$ PVP to the culture medium showed better results overall than the activated charcoal concentrations tested. A trend of improved in vitro plant conditions was observed when maintained with increasing concentration of activated charcoal, however the use of PVP was superior.

Higher oxidation percentages of the explants were obtained in the treatment with $1.0 \mathrm{~g} \mathrm{~L}^{-1}$ of activated charcoal for the first subculture, and with the use of 1.0 and $2.0 \mathrm{~g} \mathrm{~L}^{-1}$ of charcoal for the second subculture.

Table 2. Average values for the variables of vigor, chlorosis, leaf number (LN) for subculture 1, and the variables of vigor and number of shoots (NS) for subculture 2 of E. incanus, in response to the use of PVP and activated charcoal.

Tabela 2. Valores médios para as variáveis vigor, percentual de clorose e número de folhas (LN) para o subcultivo 1, e para as variáveis vigor e número de brotações (NS) para o subcultivo 2 de E. incanus, em resposta ao uso de PVP e carvão ativado.

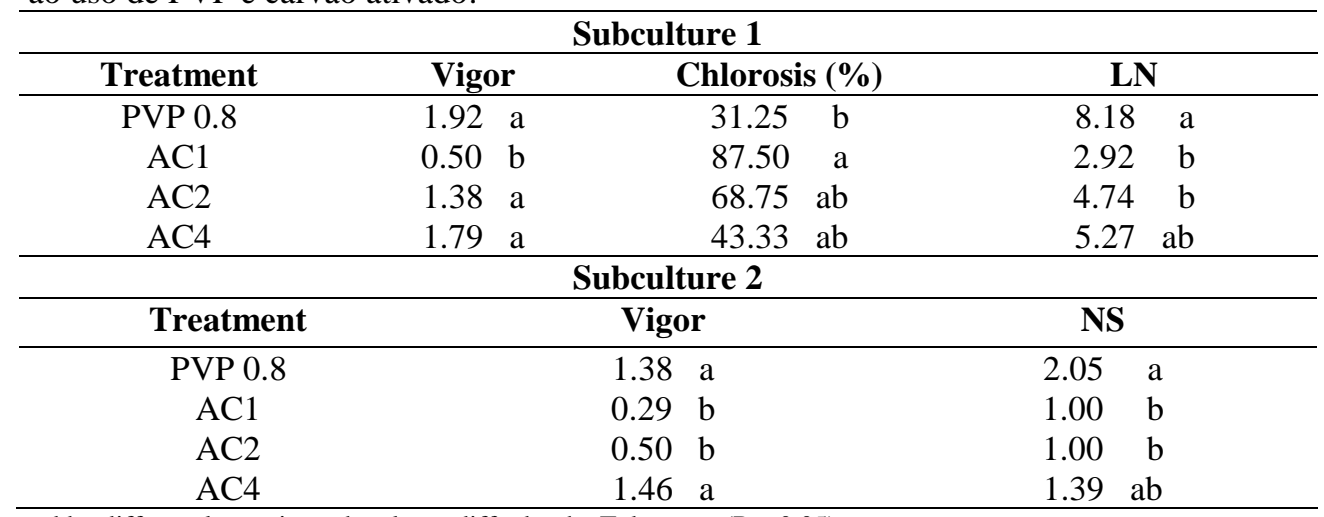

Means followed by different letters in each column differ by the Tukey test $(\mathrm{P}<0.05)$.

\section{Experiment 2 - Sucrose and agar concentrations}

In the initial culture, a significant effect of sucrose concentrations was observed for leaf chlorosis $(\mathrm{P}=0.007)$ and number of shoots $(\mathrm{P}=0.033)$ (Table 3$)$. The interaction between agar and sucrose concentrations was not significant for any of the evaluated characteristics.

Table 3. Results of the analysis of variance for the characteristics of vigor, leaf chlorosis, leaf number (LN), length of the longest leaf (LL) and number of shoots (NS) in the initial culture and subculture 1 of Eremanthus incanus, depending on the sucrose and agar concentrations.

Tabela 3. Resultado da análise de variância para as características vigor, percentual de clorose foliar, número de folhas (LN), comprimento da maior folha (LL) e número de brotações (NS) no cultivo inicial e subcultivo 1 de Eremanthus incanus, em função das concentrações de sacarose e ágar.

\begin{tabular}{cccccc}
\hline & \multicolumn{5}{c}{ Initial culture } \\
\cline { 2 - 6 } & Vigor & Chlorosis & LN & LL & NS \\
\hline $\mathrm{A}(P)$ & $1.0000^{\mathrm{ns}}$ & $0.3595^{\mathrm{ns}}$ & $0.1036^{\mathrm{ns}}$ & $0.9060^{\mathrm{ns}}$ & $0.3222^{\mathrm{ns}}$ \\
$\mathrm{S}(P)$ & $0.2019^{\mathrm{ns}}$ & $0.0065^{* *}$ & $0.2112^{\mathrm{ns}}$ & $0.1496^{\mathrm{ns}}$ & $0.0329^{\mathrm{n}}$ \\
$\mathrm{A} * \mathrm{~S}(P)$ & $0.7781^{\mathrm{ns}}$ & $0.4241^{\mathrm{ns}}$ & $0.2111^{\mathrm{ns}}$ & $0.9972^{\mathrm{ns}}$ & $0.2866^{\mathrm{ns}}$ \\
$\mathrm{CV}(\%)$ & 40.07 & 41.93 & $24.12^{5}$ & 37.92 & 36.85 \\
\hline & & \multicolumn{5}{c}{ Subculture $\mathbf{1}$} & \\
\cline { 2 - 6 } & Vigor & Chlorosis & LN & $\mathbf{L L}$ & $\mathbf{N S}$ \\
\hline $\mathrm{A}(P)$ & $0.0386^{*}$ & $0.1619^{\mathrm{ns}}$ & $0.0071^{* *}$ & $0.1783^{\mathrm{ns}}$ & $0.0716^{\mathrm{ns}}$ \\
$\mathrm{S}(P)$ & $<0.0001^{* * *}$ & $0.0187^{*}$ & $0.0064^{* *}$ & $<0.0001^{* * *}$ & $0.0164^{*}$
\end{tabular}




\begin{tabular}{cccccc}
$\mathrm{A} * \mathrm{~S}(P)$ & $0.0056^{*}$ & $0.4175^{\mathrm{ns}}$ & $0.1058^{\mathrm{ns}}$ & $0.9772^{\mathrm{ns}}$ & $0.0361^{*}$ \\
$\mathrm{CV}(\%)$ & 41.89 & 72.59 & 36.62 & 42.48 & 35.67 \\
\hline
\end{tabular}

SV: Source of Variation; DF: Degrees of freedom; A: Agar; S: Sucrose; CV: Coefficient of Variation; Limit Probabilities *: P $<0.05$; **: P < 0.01 ; ***: $\mathrm{P}<0.001$; ns: $\mathrm{P}>0.05$.

The effects of the sucrose factor were significant for all variables for subculture 1, whereas the effects of the agar were only significant for vigor and number of leaves. The effects of the interactions between these two factors were significant for vigor and number of shoots (Table 3).

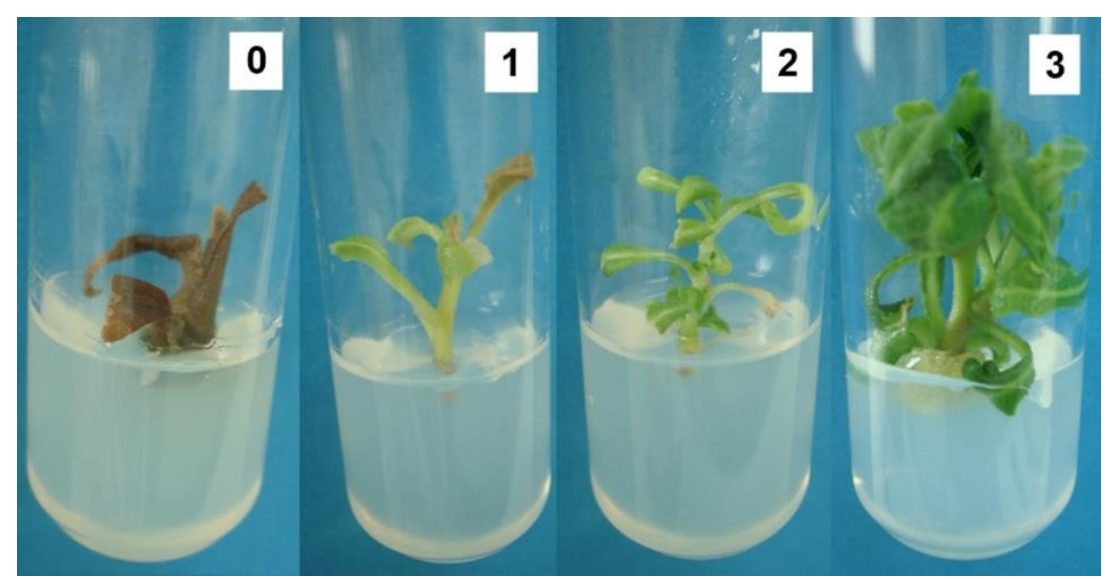

Figure 2. Classification of vigor nodal segments of Eremanthus incanus depending of the treatments. 0) oxidized, 1) low, 2) medium and 3) high.

Figura 2. Classificação do vigor de explantes de Eremanthus incanus em função dos tratamentos. 0) oxidado, 1) baixo, 2) médio e 3) alto.

The variables of chlorosis percentage and number of shoots presented a quadratic tendency in relation to sucrose concentration in the initial culture (Figure 3).
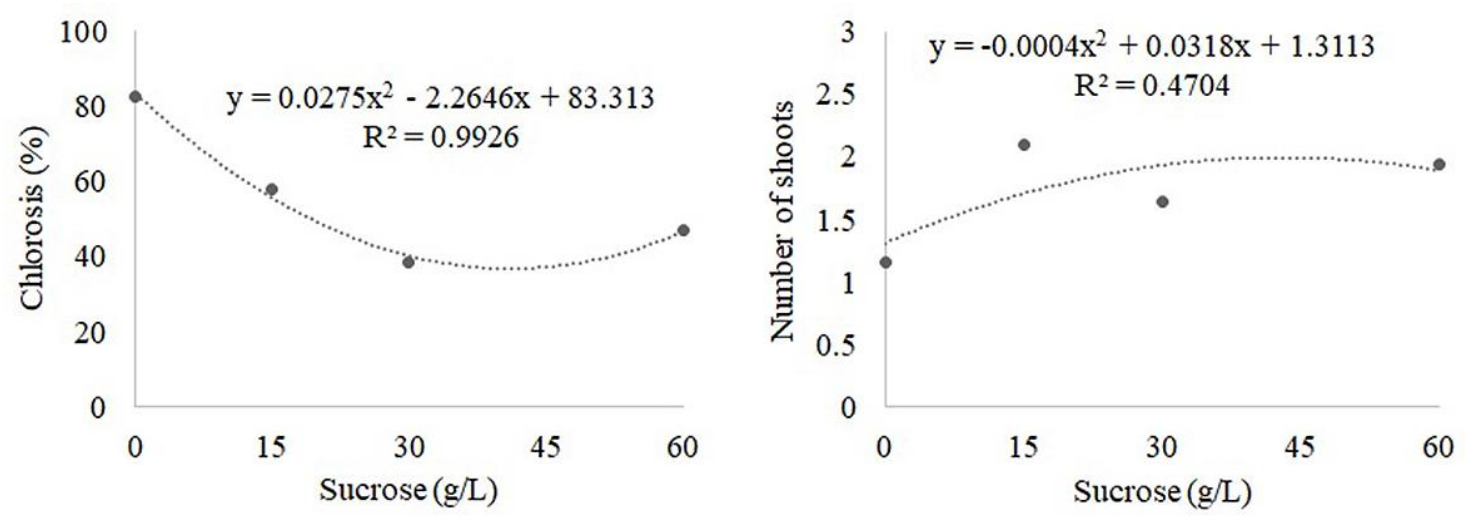

Figure 3. Percentage of chlorosis and number of shoots for the different sucrose concentrations for the initial Eremanthus incanus culture.

Figura 3. Percentual de clorose e número de brotações, em relação às diferentes concentrações de sacarose, para o cultivo inicial de Eremanthus incanus.

A difference between concentrations of agar for the first subculture was only observed when using $30 \mathrm{~g} \mathrm{~L}^{-}$ ${ }^{1}$ of sucrose. A lower vigor and smaller number of shoots were obtained with the use of $10 \mathrm{~g} \mathrm{~L}^{-1}$ of agar, while a higher number of leaves was observed with the use of $6 \mathrm{~g} \mathrm{~L}^{-1}$ of agar (Table 4).

FLORESTA, Curitiba, PR, v. 48, n. 3, p. 311-320, jul/set. 2018.

Miranda. N. A. et.al.

ISSN eletrônico 1982-4688

DOI: $10.5380 /$ rf.v48 i3.51365 
Table 4. Mean values for the variables of vigor, number of leaves, and number of shoots of Eremanthus incanus for the agar factor, agar interaction and sucrose for subculture 1.

Tabela 4. Valores médios para as variáveis vigor, número de folhas e número de brotações de Eremanthus incanus, em função do fator ágar e interação ágar e sacarose para o subcultivo 1 .

\begin{tabular}{|c|c|c|c|c|c|}
\hline \multicolumn{6}{|c|}{ Vigor } \\
\hline & & \multicolumn{4}{|c|}{ Sucrose $\left(\mathrm{g} \mathrm{L}^{-1}\right)$} \\
\hline & & 0 & 15 & 30 & 60 \\
\hline Agar & 6 & $0.55 \mathrm{~A}$ & $0.80 \mathrm{~A}$ & $2.05 \mathrm{~A}$ & $1.80 \mathrm{~A}$ \\
\hline$\left(\mathrm{g} \mathrm{L}^{-1}\right)$ & 10 & $0.40 \mathrm{~A}$ & $0.85 \mathrm{~A}$ & $0.55 \mathrm{~B}$ & $1.95 \mathrm{~A}$ \\
\hline \multicolumn{6}{|c|}{ Number of leaves } \\
\hline Agar & 6 & $8.33 \mathrm{~A}$ & & & \\
\hline$\left(\mathrm{g} \mathrm{L}^{-1}\right)$ & 10 & $5.67 \mathrm{~B}$ & & & \\
\hline
\end{tabular}

\begin{tabular}{|c|c|c|c|c|c|}
\hline \multicolumn{6}{|c|}{ Number of shoots } \\
\hline & & \multicolumn{4}{|c|}{$\begin{array}{ll}\text { Sucrose }\left(\mathrm{g} \mathrm{L}^{-1}\right)\end{array}$} \\
\hline & & 0 & 15 & 30 & 60 \\
\hline Agar & 6 & $1.13 \mathrm{~A}$ & $1.44 \mathrm{~A}$ & $2.86 \mathrm{~A}$ & $2.23 \mathrm{~A}$ \\
\hline$\left(\mathrm{g} \mathrm{L}^{-1}\right)$ & 10 & $1.17 \mathrm{~A}$ & $1.73 \mathrm{~A}$ & $1.38 \mathrm{~B}$ & $1.76 \mathrm{~A}$ \\
\hline
\end{tabular}

Means followed by different letters in each column differ by the Tukey test $(\mathrm{P}<0.05)$.

The increase in sucrose concentration provided an increase in vigor, number of leaves, length of largest leaf, and number of shoots, decreasing chlorosis (Figure 4). 
A
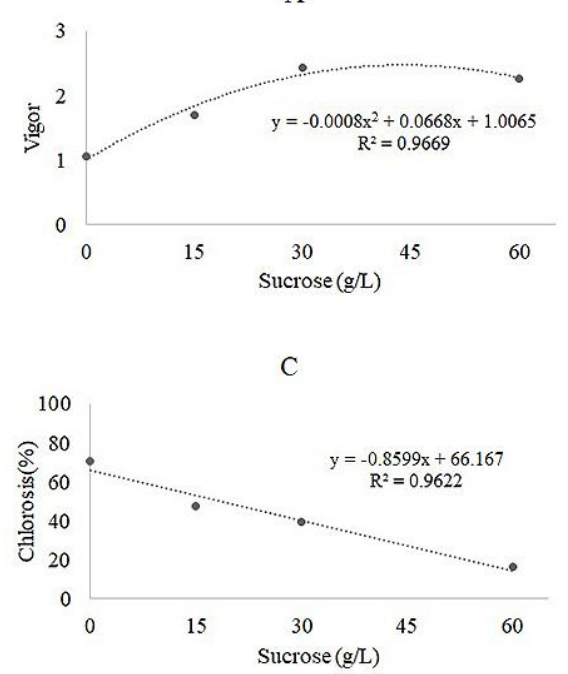

E

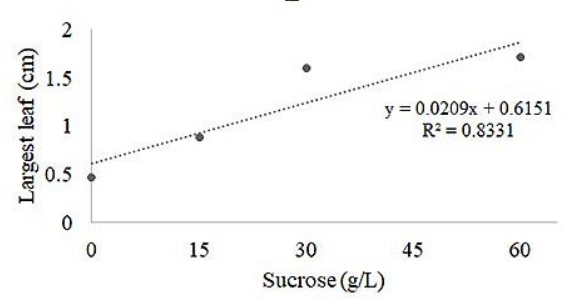

$\mathrm{G}$

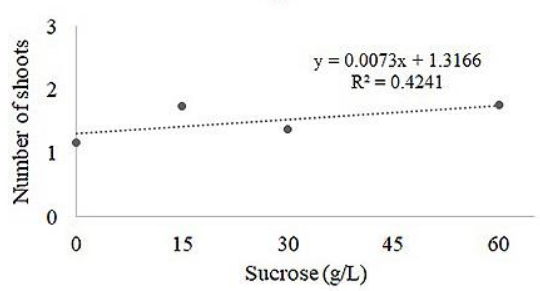

B

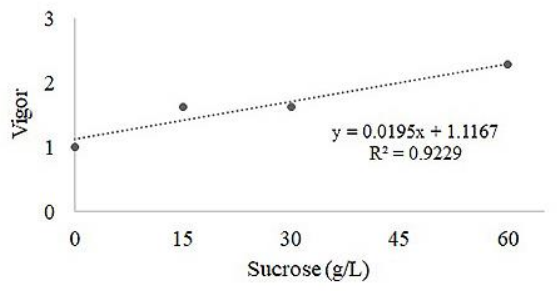

$\mathrm{D}$

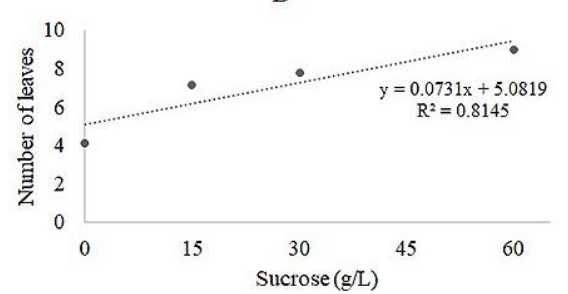

F

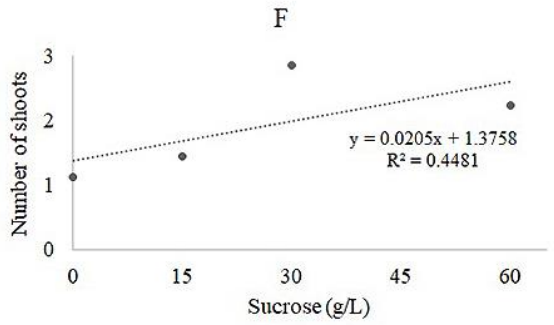

Figure 4. Vigor according to sucrose concentration using $6 \mathrm{~g} \mathrm{~L}^{-1}$ (A) and $10 \mathrm{~g} \mathrm{~L}^{-1}$ of agar (B); chlorosis percentage (C), number of leaves (D) and length of the largest leaf (E) according to sucrose concentration; Number of shoots according to sucrose concentrations using $6 \mathrm{~g} \mathrm{~L}^{-1}(\mathrm{~F})$ and $10 \mathrm{~g} \mathrm{~L}^{-1}$ agar $(\mathrm{G})$ in the first $E$. incanus subculture.

Figura 4. Vigor em função das concentrações de sacarose com o uso de $6 \mathrm{~g} \mathrm{~L}^{-1}$ (A) e $10 \mathrm{~g} \mathrm{~L}^{-1}$ de ágar (B); percentual de clorose (C), número de folhas (D) e comprimento da maior folha (E) em função das concentrações de sacarose; Número de brotações em função das concentrações de sacarose com o uso de $6 \mathrm{~g} \mathrm{~L}^{-1}(\mathrm{~F})$ e $10 \mathrm{~g} \mathrm{~L}^{-1}$ de ágar (G), no primeiro subcultivo de E. incanus.

\section{DISCUSSION}

The elements that compose the nutrient media used for plant culture of cells, tissues and organs have the main function of promoting growth and controlling in vitro development. In the control of oxidation by phenolic compounds, antioxidants such as PVP and activated charcoal can be included in the culture medium as an alternative to the problem. PVP is a water-soluble polymer, it is an antioxidant that has been widely used and has the main advantage of its property of capturing electrons, often being indicated in the control of oxidation (CID; TEIXEIRA, 2014). Activated charcoal is obtained from the thermal decomposition of carbon-rich materials, and in nutrient medium represents a thin network of pores with large surface and volume, which gives it a distinct

FLORESTA, Curitiba, PR, v. 48, n. 3, p. 311-320, jul/set. 2018.

Miranda. N. A. et.al.

ISSN eletrônico 1982-4688

DOI: $10.5380 /$ rf.v48 i3.51365 
adsorption capacity (THOMAS, 2008). Activated charcoal is often used in tissue culture to enhance cell growth and development (XAVIER et al., 2013).

The main effect of activated charcoal is related to the adsorption capacity of the metabolites produced by the in vitro explants, as well as reducing the toxic effects of substances such as 5-hydroxymethylfurfural, which is produced from sucrose dehydration during autoclaving, or the inhibitory substances present in the agar or also to reduce the action of toxic metabolites such as phenolic substances, ethylene and abscisic acid which are eliminated by the explant (THOMAS, 2008). However, the non-selective effect of activated charcoal adsorption may cause the nutrient removal, being important hormones for plant development. The inferiority of activated charcoal in relation to PVP observed in most of the analyzed variables in this study may be due to the adsorption of plant essential components by this additive.

Werner et al. (2009) studied propagation procedures of Caesapinia echinata using some antioxidants such as ascorbic acid, citric acid and activated charcoal. They noted that the incorporation of activated charcoal $\left(2.0 \mathrm{~g} \mathrm{~L}^{-1}\right)$ in the culture medium was the best treatment for oxidation control, where $40 \%$ of the explants showed low oxidation, but it was in the presence of ascorbic acid the greatest callus formation was found. For the Fragaria chiloensis species the addition of PVP improved the meristematic regeneration efficiency, reducing oxidation levels (QUIROZ et al., 2017). In their study with Bowdichia virgilioides, Moura et al. (2012) pointed out the importance of activated charcoal on shoot quality, providing a lower percentage of leaf chlorosis and a higher percentage of well-developed plants compared to PVP.

Sucrose also plays an important role in in vitro cultures, as it provides energy and carbon for plants (GEORGE et al., 2008). The carbon source concentration added to the culture medium can significantly influence the plant's yield due to its effects on the energy supply to the explant and the osmotic potential maintenance of the medium (RIBEIRO et al., 2015).

According to Xavier et al. (2013), plants usually grow in heterotrophic condition in the in vitro condition, depending on an external source of energy. This fact corroborates the results found in this study, when an inferior performance of the plants (greater leaf chlorosis percentage, smaller number of shoots) was observed when an energy source was not added to the culture medium $\left(0 \mathrm{~g} \mathrm{~L}^{-1}\right.$ of sucrose $)$.

Sucrose is the most common carbon source used to grow cells, tissue, and plant organs in a heterotrophic system. On average $30 \mathrm{~g} \mathrm{~L}^{-1}$ of sucrose are added to the medium since the formulation of MS medium by Murashige and Skoog in 1962. The sucrose content used in plant tissue culture is important as an energy source, ensuring plant development; although other important roles such as carbon precursor or metabolite signaling have been more recently highlighted (GAGO et al., 2014).

The positive effects of using sucrose in the medium have been explored for many years, although there are studies reporting negative effects which suggest reducing or removing sucrose from the medium, since exogenous sugar is one of the main causes for plant stress during in vitro cultivation (KOZAI et al., 2005). The high sucrose content in the medium can reduce photosynthetic growth and the expression of genes related to photosynthesis (KOZAI et al., 2005, BADR et al., 2011), and promote physiological and structural formation of abnormal stomata (HAZARIKA, 2006).

Several studies have demonstrated the importance of using sucrose in the culture medium for in vitro cultivation of different species. In the micropropagation multiplication stage of Dioscorea multiflora in testing different concentrations of BAP and sucrose, Souza et al. (2011) observed that the medium supplemented with 20 $\mathrm{g} \mathrm{L}^{-1}$ of sucrose and $0.1 \mathrm{mg} \mathrm{L}^{-1}$ BAP resulted in a greater number of shoots and longer shoots for the species.

In studying procedures for in vitro establishment of three species of the genus Ocotea, Moritz et al. (2009) found that the plants presented slow but healthy development with $30 \mathrm{~g} \mathrm{~L}^{-1}$ of sucrose, while the use of higher concentrations (90 and $120 \mathrm{~g} \mathrm{~L}^{-1}$ ) negatively influenced plant development. Also according to the authors, higher concentrations of sucrose probably caused a certain degree of plant toxicity. Bandinelli et al. (2013) observed that the increase in the sucrose concentration reduced the number of leaves and the length of Solanum tuberosum shoots/buds.

Another element commonly used in semisolid culture media is agar (XAVIER et al., 2013). Agar is a polysaccharide extracted from algae that forms a gel when solubilized which can bind to water and adsorb compounds. The higher the concentration, the stronger the water bond will be (PIERIK, 1997). Agar is used in tissue culture to support explants and plants maintained in vitro. It offers the advantage of being water soluble and remaining semi-solid at room temperature. Concentrations between 5 and $7 \mathrm{~g} \mathrm{~L}^{-1}$ are generally used, however there are also records of higher concentrations to mainly control the vitrification of plant material (CID; TEIXEIRA, 2014).

Agar has the advantage of forming a colloid when added to water, not reacting with the constituents of the medium (GEORGE, 2008). Chemical and physical characteristics of culture medium, and consequently in vitro plant responses are affected by agar quality and concentration, mainly due to the presence of associated organic 
and inorganic inhibitors (ROMBERGER; TABOR, 1971). Higher agar concentrations hinder the contact between explant and the medium, and therefore if the concentration is increased, the compound absorption by the explant and nutrient diffusion is hindered (PIERIK, 1997).

For Eremanthus incanus, the increase in agar concentration promoted developmental reduction, possibly due to the increase in the osmotic potential of the culture medium which hinders nutrient diffusion to plants. On the other hand, in analyzing Eriobotrya japonica, Nogueira et al. (2015) found a linear increase in the pollen germination percentage as the agar concentration increased. The same behavior was observed in relation to the addition of sucrose to the culture medium. According to the authors, a possible explanation for the agar is that the high concentration of this solidifying agent allowed greater consistency of the culture medium, which promoted the osmotic potential balance of the medium. Regarding the effect of sucrose addition, they suggest that it must be related to the supply of metabolic energy and carbon skeletons for the biosynthesis of organic compounds necessary for cell growth.

\section{CONCLUSIONS}

- The multiplication of Eremanthus incanus axillary buds presented a better response with the use of the PVP antioxidant in the concentration of $0.8 \mathrm{~g} \mathrm{~L}^{-1}$, being more efficient than the addition of activated charcoal in the culture medium to improve the quality and quantity of shoots.

- Under these conditions, the use of sucrose is indispensable for the proper development of plants in vitro. The effect of sucrose and agar concentrations are independent, achieving better rates of shoot multiplication and quality with the use of $30 \mathrm{~g} \mathrm{~L}^{-1}$ of sucrose and $6.0 \mathrm{~g} \mathrm{~L}^{-1}$ of agar.

- Thus, the effects of different sucrose, antioxidant and agar concentrations indicate that these components represent important factors in the search for efficient protocols for Eremanthus incanus micropropagation.

\section{ACKNOWLEDGEMENTS}

The authors would like to thank the Federal University of Jequitinhonha and Mucuri, CAPES and FAPEMIG. Special thanks to the staff at the Forest Improvement Laboratory and forest nursery of the UFVJM.

\section{REFERENCES}

BADR, A.; ANGERS, P.; DESJARDINS, Y. Metabolic profiling of photoautotrophic and photomixotrophic potato plantlets (Solanum tuberosum) provides new insights into acclimatization. Plant Cell, Tissue and Organ Culture, France, v. 107, n. 1, p. 13-24, 2011.

BANDINELLI, M. G. BISOGNIN, D. A.; GNOCATO, F. S.; MAMBRIN, R. B.; SAUSEN, D.; NICOLOSO, F. T. Concentração dos sais e da sacarose do meio MS na multiplicação in vitro e na aclimatização de batata. Horticultura Brasileira, Vitória da Conquista, v.31, p.242-247, 2013.

CAMPOS, V. C. A., LIMA-BRITO, A., GUTIERREZ, I. E. M. D., SANTANA, J. R. F. D., SOUZA, A. V. V. Micropropagation of umburana de cheiro. Ciência Rural, Santa Maria, v. 43, n. 4, p. 639-644, 2013.

CID, L. P. B.; TEIXEIRA, J. B. Explante, meio nutritivo, luz e temperatura. In: CID, L. P. B. Cultivo in vitro de plantas. Brasília: EMBRAPA, 2014, 325p.

FERREIRA, E. B.; CAVALCANTI, P. P.; NOGUEIRA, D. A. ExpDes.pt: Experimental Designs Pacakge (Portuguese). R package version 1.1.2. 2013.

GAGO, J.; MARTÍNEZ-NÚÑEZ, L.; LANDÍN, M.; FLEXAS, J.; GALLEGO, P. P. Modeling the effects of light and sucrose on in vitro propagated plants: a multiscale system analysis using artificial intelligence technology, PLoS ONE, California, v. 9, n. 1, 2014.

GEORGE, E. F.; HALL, M. A.; KLERK, G. J. de. Plant propagation by tissue culture, Volume 1: The Background.3. ed, 2008, 5001p.

HAZARIKA, B. N. Morpho-physiological disorders in in vitro culture of plants. Scientia Horticulturae, Cape Town, v. 108, n. 2, p. 105-120, 2006.

FLORESTA, Curitiba, PR, v. 48, n. 3, p. 311-320, jul/set. 2018.

Miranda. N. A. et.al.

ISSN eletrônico 1982-4688

DOI: $10.5380 /$ rf.v48 i 3.51365 
KOZAI, T.; AFREEN, F.; ZOBAYED, S. M. A.Photoautotrophic (sugar-free medium) micropropagation as a new micropropagation and transplant production system. Springer, p. 316, 2005.

MORITZ, A.; DEGENHARDT, J.; DUTRA, L. F.; HANSEL, F. A.; LIMA, B. H. de; FRANCESCHI, C. do R. B.; FRANCISCON, L. Estabelecimento in vitro de Ocotea odorífera, O. catharinensis e O. porosa. Pesquisa Florestal Brasileira, Colombo, n. 59, p. 37-44, 2009.

MOURA, L. C. de; TITON, M.; FERnANDES, J. S. C. SANTANA, R. C.; OliVEIRA, M. L. R. de. Micropropagação de sucupira-preta por meio de gemas axilares. Pesquisa Agropecuária Brasileira, Colombo, v.47, n.12, p.1691-1698, 2012.

MURASHIGE, T.; SKOOG, F. A revised medium for rapid growth and bioassays with tobacco tissue cultures. Physiologia Plantarum, Copanhagen, v.15, n. 3, p.473-497, 1962.

NOGUEIRA, P. V.; SILVA, D. F.; PIO, R.; SILVA, P. A. O.; BISI, R. B.; BALBI, R. V. (2015). Germinação de pólen e aplicação de ácido bórico em botões florais de nespereiras. Bragantia, Campinas, v.74, n.1, p.9-15, 2015.

PIERIK, R. L. M. In vitro culture of higher plants. 4.ed. Netherlands: Kluweer Academic Publishers, 1997, 348 p.

PINHAL, H.F.; ANASTÁCIO, M. R.; CARNEIRO, P. A. P.; SILVA, V. J. da; MORAIS, T. P. de; LUZ, J. M. Q. Aplicações da cultura de tecidos vegetais em fruteiras do Cerrado. Ciência Rural, Santa Maria, v.41, n.7, p.11361142, 2011.

QUIROZ, K. A.; BERRÍOS, M.; CARRASCO, B.; RETAMALES, J. B.; CALIGARI, P. D. S.; GARCÍAGONZÁLES, R. Meristem culture and subsequent micropropagation of Chilean strawberry (Fragaria chiloensis (L.) Duch.). Biological research, Chile, v. 50, n. 1, p. 20, 2017.

R CORE TEAM. R: A language and environment for statistical computing. R Foundation for Statistical Computing, Vienna, Austria. 2013. Disponível em: <http://www.R-project.org/> Acesso em 21 Julh. 2013.

RIBEIRO, M. F.; RITTERBUSCH, C. W.; BIANCHI, V. J.; PETERS, J. A. Fontes de carbono na multiplicação in vitro de porta-enxertos de marmeleiro 'MC' e 'Adams'. Plant Cell Culture \& Micropropagation, Chichester, v. 11, n. 2 , p. 54-61, 2015.

ROCHA, H. S. Biofábricas: estrutura física e organização. In: JUNGHANS, T. G.; SOUZA, A. da S. Aspectos práticos da micropropagação de plantas. Cruz das Almas: Embrapa Mandioca e Fruticultura Tropical, p. 121$152,2009$.

ROMBERGER, A.; TABOR, C. A. The Picea abies shoot apical meristem in culture I. Agar and Autoclaving Effects. American Journal of Botany, Connecticut, v. 58, n. 2, p. 131-140, 1971.

SCOLFORO, J. R. S.; LOEIULlE, B. F. P.; ALTOÉ, T. F. Caracterização da candeia. In: SCOLFORO, J. R. S.; OLIVEIRA, A. D. de; DAVIDE, A. C. O manejo sustentável da candeia: o caminhar de uma nova experiência florestal em Minas Gerais. Ed. UFLA, Lavras, 2012, p.19-27.

SOUZA, A. V. D., BERTONI, B. W., FRANÇA, S. de C., PEREIRA, A. M. S. Micropropagation of Dioscorea multiflora Grised. Ciência e Agrotecnologia, Lavras, v. 35, n. 1, p. 92-98, 2011.

THOMAS, T.D. The role of activated charcoal in plant tissue culture. Biotechnology Advances, v.26, p.618-631, 2008.

WERNER, E. T.; CUZZUOL, G. R. F.; PESSOTI, K. V.; LOPES, F. P.; ROGER, J. de A. Controle da calogênese do pau-brasil in vitro. Revista Árvore, Viçosa, v. 33, n. 6, p. 987-996, 2009.

XAVIER, A.; WENDLING, I.; SILVA, R.L. Silvicultura Clonal: princípios e Técnicas. Ed. UFV, Viçosa, 2013, 279 p. 